\title{
Deleuze and Collaborative Writing in the Dance of Activism
}

\author{
Ken Gale, Jonathan Wyatt, Jessica Smartt Gullion, \\ Ninian Hou, Christopher Jeansonne, Sheridan Linnell, \\ Melanie A. Reaves, Rosemary Reilly, and Paul Rhodes
}

\begin{abstract}
Drawing upon and infused by the 'micropolitical' moves of Deleuze and Guattari, this article arose out of a participative workshop at the 2018 International Congress of Qualitative Inquiry that took up Braidotti's proposition to explore how collaborative writing 'like breathing, [is] not held into the mould of linearity, or the confines of the printed page, but move[s] outwards, out of bounds, in webs of encounters with ideas, others, texts' (Braidotti, 2013, p. 166). We worked with the view that collaborative writing is a political act, a 'minor gesture' (Manning, 2016), a world making that opens up to the new and challenges the sedimented. This is an article that engages in and with collaborative writing, that dances with ideas of what collaborative writing might be and, crucially, what it might do.
\end{abstract}

Keywords: collaborative writing, activism, Deleuze and Guattari, dance

\section{The Prelude}

We (Ken and Jonathan) were given the opportunity by the conference organisers of the 14th International Congress of Qualitative Inquiry in May 2018 to run a preconference workshop on 'Deleuze, Collaborative Writing, and Activism'. In preparation for this and following the thinking of Spinoza, we decided that the workshop would provide us with a means of opening up a space with the workshop participants of exploring and inquiring into what collaborative writing could $d o$.

In this way we felt it would be possible to shift the direction and impetus of the workshop practice, primarily at least, away from an inquiry into what collaborative writing is or what it might mean, and move it towards active and activist participative 
engagement with what bodies of writing 'creative-relationally' (Massumi, 2015, p. 14) with one another could animate and actually do. By drawing on the thinking and practice of Deleuze and Guattari (1987), we decided to design a series of encounters that would work with the sense in which participation in the workshop would open up new spaces of inquiry. Deleuze and Guattari have said: 'But when one writes, the only question is which other machine the literary machine can be plugged into, must be plugged into, in order to work' (p. 4). So, in our design and ensuing collaborative workshop practice, we used 'ideas, fragments, theory, selves, sensations ... to engage plugging in as a process' (Jackson \& Mazzei, 2012, p. 1). Therefore, we decided to facilitate the opening up of a collaborative intra-active space in which participants were relatively free to creatively and diffractively enact and respond to multiple stimuli, movements in moments, in the processually imaginative unfolding of (listening, talking, writing, listening, talking, writing...) space.

The workshop began with the introductions 'zigzag' exercise that we have described previously:

The exercise runs as follows: Each person introduces himself or herself to one other member of the group, across the circle, with the rest as witnesses; 'respondents' listen, allowing thoughts, feelings, and connections to emerge before, in turn, introducing themselves to another member of the group. When the spoken introductory zigzag is complete, each writes a response to the other's introduction. Writings are passed to the respective 'introducer' (a second zigzag moment, as people stand to give in one direction and receive from another), and these writings are responded to with further writing which, once complete, is passed back in further zigzagging.

The exercise draws on Deleuze's use of the zigzag, which, he says, illustrates bringing 'singularities into relationship' (Boutang, 1996). The process, with each member of the group connecting with others, also illuminates the Deleuzian notion of assemblage, which Deleuze used to challenge the scientific reductionism emerging from the Enlightenment thought that perpetuates the ascendancy of neo-liberal individualism. Deleuze argued that whilst we can talk of singularities of self, we need to do so in relation to multiplicities. (Guttorm et al., 2012, p. 379)

This led into us offering the following piece of writing ${ }^{1}$ as a reading prompt and asking the participants, on listening to the reading, to write down/through/into their 
responses. In this writing the group, members were encouraged to respond in whatever way they felt appropriate to or in line with their feelings and affective dispositions in relation to what Ken and Jonathan had to say in their reading. We then invited sharing these writings within the group.

\section{The Reading Prompt}

Ken

As always in moments like this, my movements in opening another writing space give me a sense in which I am writing to you (Jonathan). In materiality, the flesh and bloodness that is constitutive of the 'you' that I have been opening up writing spaces with for more than 10 years continues in its intensive presencing, always generative of great potential, always in the knowing that something new, something useful, something worthwhile, and something deeply affective will be emergent. With Barad (2007), I am also deeply aware that this materiality, no, these materialities, are fundamentally and, in always ever-changing ways, inevitably entangled with multiple discourses that are always there, animate in their intention to construct me in particular ways. I am going to try to bring this to the fore in this little piece of writing about collaborative writing and activism.

\section{Jonathan}

Our Sundays since last year have found a new rhythm that day of the week hasn't had since the years way back before you (Ken) and I met, before ICQI, before collaborative writing even, when I would go to church. We wake up not too early, dress in or take with us the requisite clothing and walk 10 minutes west into Stockbridge, a village within the city. We walk its quiet high street and turn left and along to a nondescript two-storey 1970s concrete building out of keeping with its Georgian surroundings. We take the stairs towards the music and enter the circular room. On a good day the sunlight enters through the skylights on the far side. A few are there already. Others arrive over the next 30 minutes, a gradual expansion as we, all of us, begin moving in and around each other on the wooden floor. This is what we now do on Sunday mornings and again on Wednesday evenings: we dance, an open, unfolding, slow-fast, intimate travelling of and between bodies. It's been an important discovery for me, this dancing. I feel I have found my feet, at last. 
Ken

I remember coming to the congress with you in 2010 and before we travelled south, staying in Chicago with Soyini (Madison) for a few days. It was the year her book Acts of Activism (Madison, 2010) was published, so I also remember in the conversations we held with her at the time being deeply impressed by the notion of acts of activism. The arguments that she developed from her ethnographic field work in Ghana with local activists who were employing modes of performance as tactics of resistance and intervention in their day-to-day struggles for human rights were, and remain, very powerful. Her portrayal of the dynamic relationship between performance and activism, both in those conversations and subsequently when reading her book, had and continue to have a profound effect upon me and upon the research practices with which I engage.

I understood acts of activism, initially in my direct sensing of Soyini's spoken and written words, in terms of bodies performing themselves in forms of action that would bring about some kind of change and, obviously, in terms of the rhetoric of Soyini's project, this change would be for the good, it would be to enhance equality and to challenge injustice in the world. At the time, I'm sure you will remember, I was greatly assisted in forming this understanding through working with the simple, direct, and hugely animating performative question that Ron (Pelias) asks of a particular performative act: What work does it do?

This is an enormous and powerfully important question to ask of a body, of a body in action, and of an act of activism: What work does it do?

\section{Jonathan}

Yesterday we gathered in a circle on the floor at the end, some two hours after we began, and held hands. One of us spoke into the stillness, 'This feels so important, this, our dancing, given what's happening in the world, given the madness'. Another spoke of a march in support of the environment she was helping to organise, how there would be a gathering of dancers as part of it and who would like to join?

I had been sensing this too over recent months, how this act, this commitment, was becoming an act of resistance. I had heard about dance protests on the Golden Gate Bridge, at Standing Rock, and elsewhere. I couldn't articulate my participation as activist, and I'm not sure yet whether I can. But I want to propose how that Sunday morning walk from home, past the waking market to that upstairs room of sound and sweat, gestures and shapes, speed and slowness, is an act of activism. It is a bringing 
of the multiple (human, nonhuman, more-than-human) bodies together onto a stage, into engagement; it is a move towards both vulnerability, as we become alert to our mutual intradependence, and strength - as we become alert to our mutual intradependence.

\section{Ken}

For me, as you will probably guess, it is not enough to talk about the work that is done by bodies that are simply human. Posthuman thinking and theorising teaches us that we have to think about bodies, all bodies, in relationality. It is not enough to talk only and in isolation about human bodies; this involves us in committing the major crime of living in the Anthropocene. With these concerns to do with collaborative writing and activism, within a consideration of acts of activism, when asking such questions as What can a body do? What work does a particular performance or act do? we are impelled to bring nonhuman as well as human bodies into these relationalities. Having paid great attention to the work of Spinoza (2002) and to what might now appear to be, in relation to the relevance of this to my research, the expression of a mantra, I am convinced that all bodies, human and nonhuman, have the capacity to affect and be affected. I can no longer understand power outside of the micropolitics of this.

\section{Jonathan}

We call it dance, but the word slips along with our skin as it touches others', as feet, backs, and hands encounter the warming floor pressing back on us. We call it dance. It's what it does that matters, the work it does, the work bodies do.

You may have spotted a clumsy, over-signalled analogy, but I think I'm saying collaborative writing is something like this dancing. Or can be. Collaborative writing is/remains the dance we make, the vital, ritual bringing of multiple bodies onto page/ stage, intimate and vulnerable, angry and strong, necessary and problematic, "[posthuman] flesh to [posthuman] flesh scholarship' (Spry, 2001, p. 726).

\section{Ken}

What does collaborative writing do? I also like to use the figure of the 'dance' to help me with my sensing with and of relationality. To use dance as a means of describing the doings of collaborative writing is a good thing because dance is about 
relationality, it is about the capacity to affect and be affected. Dancing involves touch, and touch cannot live in the singular. In the dance touch is multiple and complex, it is about movement, intensity, and potentiality, it never resides, it lives in the creation of the next moment, the next step into the not yet known. In the dance touch is promiscuous, touching is gestural, political, affective, and always more than the simply human. Touch is about actively creating new concepts, living in affect, and animating a politics of the event. In Stewart's (2010) terms, it is about 'worlding' and reaching out to the world. An activist collaborative writing has to live in and create these worldings and engage movements that are all about what bodies do and can do.

\section{The Responding}

The following are the responses that the participants each wrote and then shared with the group. In the moments of sharing there was a palpable affective movement within the group. As the workshop moved towards its conclusion, Ken, moved by the readings, suggested to Jonathan and the group that if they would like to write up and send their written response pieces to Ken and Jonathan, they would collect and collate them and dispatch them to all the group members in a composite file for further consideration and thoughts about what might be done with them. In no particular order, here are the responses from the workshop participants in exactly the form that they were sent to Ken and Jonathan subsequent to the end of the workshop and the conference.

\section{The Responses}

\section{Christopher}

In Ken and Jonathan's piece, they wrote of dance as a metaphor for collaborative writing: It is connective, it 'cannot live in the singular', it is relational; it is always emerging and productive. It is fascinating to think of Jonathan making the discovery about how his personal dance experiences are reflective and generative, connective, with his writing process, and how Ken then connects it with their collaborative writing process. Hearing them read back their dialogue, though, I also think of the fact that dance can come in many forms, even if all are relational and connective in some way. But before we become too prescriptive with the metaphor ... the kind of dance we're speaking of here is a certain kind of dance, no? My mind goes to the huge variety of things that we refer to as dance: 
Ballroom dance is formal, prescribed, controlling, where we succumb to or are embraced by social politeness. There is a sense in which the formality, rather than being just stifling, can be freeing; within the restrictions of that kind of formal dance, the smallest difference of rendering can become surprisingly evocative (though perhaps only for those who already know the tradition of the particular dance you're looking at).

In traditional Japanese dance, like Noh, again, the formal and prescribed yields attention to finer difference. And here, the thing we call dance is not relational in quite the same way, in its drama. Or in communal festival dance in Japan, it is communal but also individual and meditative. If one were to picture a meditative and mindlessly repetitive version of celebratory line dancing, but at the same time a communal experience that is at once exultant and transformative, this would be it. And so many other versions of dance around the world capture that feeling.

And then I think of American jazz dance and the various iterations of those popular forms in this country, which have had such a subversively transgressive and communal meaning that compliments the kinds of transgressive and communal traditions that jazz music embodies.

And then, as an arts educator, my mind runs to teaching and how it is both a communal experience, and one that is relational, but one that, in many of its 'traditional' forms, has been seen as a method of cultural and social control ... how might the metaphor play out in that endeavor?

\section{Sheridan: Dancing on Oliver's Hill}

I don't remember how or why I went to the ballroom dancing class in the church hall on Oliver's Hill. The hill rose above the town of Frankston, itself a cut above the A.V. Jennings housing estate of Karingal, where I lived with Mum, Dad, and my would-be runaway younger brother, caught by the police in the early hours after hitchhiking all the way to the New South Wales border. The night before my brother and his mates left, he had sat at the foot of my bed, checking out, I belatedly realised, whether I'd be OK without him.

I was so excited when the new man asked me to dance. Although his hair was cut unfashionably short, he, Brad, had been to Macquarie University in Sydney, had studied history before dropping out and coming to live with his bald-headed, opinionated uncle - the one who had insisted on the haircut. Brad was on the lookout for a convenient local girlfriend, local because he did not have a car, girl because he had moved states to avoid the mounting evidence that he mostly preferred other men. 
With hindsight, I could say we were queerly attracted to each other. He was, for me, an exotic creature. No one in my family had finished high school, let alone gone to university, or, unimaginably, 'dropped out'. Also, he was a head taller than me, a relief to a gangly, freckled schoolgirl yet to escape the grip of dominant gender discourse and who wanted to evade the grip of an earnest young mechanic whose admiring gaze uncomfortably approximated the height of her double A cupped breasts.

What am I doing standing back here against the weatherboard wall of an echoing church hall with scarified wooden floors? What slit in time did I pass though at the mention of the formality of ballroom dancing? To what point of diffraction am I taken, then and now, by the phrase, "May I have this dance?"

A phrase that welled into pregnancy and hurried marriage, uprooted me from the sandy soil of the Mornington Peninsula and flung me howling through the clouds into another city.

Recently, I gathered with other women in that same city where we lived - where I still live and you died - for the 'arts-based collective biography workshop on death'. Together with the rich materials collected and recollected on that day, I made a portrait of you, tearing ${ }^{2}$ up, tearing through layers of paper and grief.

And now I am far from home in the rural heart of the Midwest of another country, in another circle made of stories. Lightning zigzags of connection and disjunction, recognition and refraction transect the spacetime of the conference workshop. 'I' am pierced by unexpected reciprocities and frictions. A random phrase dislodges a sedimented memory that rolls through me, stretches me out, folds me further back in time.

It began with the dance. Pressing us together and spinning us around, the awkward intra-action of prescribed moves, hesitant limbs, and entangled fingers, the uncertain charge between slightly sweaty hands. Shy and clumsy, we are moving in a syncopated rhythm, always a little out of step, and from that syncope, that stumbling, swooning moment, so many (of my) lives are born.

\section{Jessica}

It is synchronous you would write/speak about dance/activism/collaboration. That is the topic of my presentation at ICQI: Dance as place/knowing, as embodied response to the crises of the Anthropocene.

I am thinking still about how we do knowledge work in the ontological turn. I've just written a book about this, but I feel the question still, smooth like a river stone, persistent. 
We dance as a move to break free of the nature/culture binary, to feel the earth on our bare feet, to connect to that which is outside/beyond/other than words.

This piece makes me also think about how I could better engage in collaborative writing. As Barad (2007) asks, do we really own any of our ideas, do we have a bounded identity, or is this all an entanglement and our perception of individuality a fantasy we use to make sense of incoming stimuli? If so, how might we express that on paper, in words? Or can we?

\section{Claire $^{3}$ : A tango of sorts}

I have rambled out my thoughts, and I'm not sure what it means to write this. I do know that the action of dancing was the most appealing idea in the pieces that were read. I'm not sure that I can think that every thing is merely a becoming, emerging from discourse or ideas of difference. What about poverty and starvation? What about social structures, physical and institutional, and how these impact on our bodies? How do we respond? With resistance, with compliance, with complicity, or with philosophy?

I see now that I am writing a series of questions, which perhaps betrays my uncertainty. Yet, I feel this strong resistance to abstraction, a sense of wanting to stay with action, acting, and activism. I do not simply choose to become; I'm shaped by relations and interactions. By what happens as bodies interact in different social spaces? I want to contest this.

So the idea of dance was appealing. It is a sort of dance, but not always as pleasurable as was described. Sometimes interactions are violent and painful. I did not choose to become, but I am a woman. It was decided. Because of this I have experienced violence. I am also white; I am part of a system that brings violence to others. This must be acknowledged.

\section{Melanie: The Literate Dance}

The computer sat there as always, waiting to be touched, listening to the work of the human bodies in the room-hers and mine. Her 9-year-old goal, to share something she had learned about cheetahs in a digital story. My goal, to help her figure out the obstruction in her way. She wrote, read, then recorded her narration. But something stood in her way. She couldn't see it. At this point, the computer was crying out, “I know, I know!!!” But I wasn't listening. I could hear the obstruction in her recorded narration - no pause, no inflection, no prosody. I had played it back to her in hopes 
she would hear it. But she didn't. She left the room that day a bit deflated. Me too. Time was up. I simply said, 'Don't worry, we'll work on it next week', to which the computer just sighed in frustration.

The next day, its message got through to me - 'She can't hear it, but she can see it'. I jumped out of my chair as I realized its message. The answer was right there the audio editing program, Audacity. Its beautiful waveform colorways and spectrograms could show her the doing of her voice. The next week she entered the room with less bounce than usual, thinking of our problem - it was our problem, not just hers. We were in this literate dance together. The computer and I excitedly revealed her narration - the audio|visual dialectic. As I explained the relations between her voice and the outstretched waveform in front of her, her hand reached for the mouse to click the 'play' arrow. It was as if the computer had tapped me on the shoulder and asked if it could 'cut in'. So, I gently stepped away and watched their bodies connect and rhythmically enter the dance floor together. The computer responded to her warm, smooth hand as she guided the cursor. As they twirled and stepped intricate patterns, she excitedly responded to the visual it laid before her - 'Oh! I didn't even stop here!' and 'My voice is so blue, I need to be more excited!'

She then realized she didn't know the steps to this dance. She turned back to me. Like any eager dance teacher, I showed her how to perform this particular dance. When she was ready, she turned back to the computer, which had waited patiently for her. Off they flew onto the dance floor as she rerecorded her narration, uploaded the file into Audacity, and clicked 'play' to see her voice. And so flowed our literate dance together for the remainder of this project of ours; I taught her literate steps, and her computer partner brought her dancing to life.

Some thoughts to this piece...

As I listened to your collaborative piece, the dancing I heard in it brought me to my recent ponderings about the dance we have with the nonhumans in our worlds from a posthuman perspective. In this case, this nonhuman made our humanity realized in tangible ways. Thank you for the opportunity to engage in writing as inquiry.

\section{Ninian Hou}

Everything was still, absolutely still. At that moment, the time froze. It's a splendid final strike.

He walked down the platform with protective gear in his hand and gave me a smile. 'How's my Wushu performance?' he asked. 
'Outstanding! You said this is your first time to attend such high-rank sporting contest, doesn't it?'

'Just like you, my friend. This is your first time being a delegation attaché, and me, first time playing the Universiade'. We both laughed.

Back to the ring, the competition began. I was amazed, indeed. How could a Brazilian player perform Wushu in a such vivid manner? To me, or maybe to most of the Chinese, Wushu isn't just a sport, it's a combination of force and beauty. To be more precise, it's a work of art.

'I got it! I got it!' I said to myself. Focusing on his movement, I began to realize that he's not trying to win the game but pursuing the pith and marrow of Wushu instead. With his rival, they danced, fist-to-fist and body-to-body. Wushu itself is a flamboyant style of choreography, and the players are impromptu choreographers. By interpreting the soul of martial art, they've sublimated hatred and violence to a new extent, dancing with their foes and dancing with their souls. They're not fighting, they're dancing.

I stood straight and stared at the players. Everything was still, absolutely still.

Paul

I was taken back through the dance, to when I was at Bergasse 19 in 2017, visiting the empty rooms and bookshop and cafe celebrating Freud.

Freezing in my beanie, worried and fascinated by the turn of the century, I remember a phrase someone told me that the body is the new unconscious.

In the quiet wooden rooms, crackling documentary, and then taking the bus with my wife up to some small village I can't remember the name of.

I was taken back through the dance.

We walked and talked, and I remember thinking about the body and my reintroduction to it many years ago... like dancing, but in my life running, through cityscapes and the bush, I was taken back through the dance.

I was taken back through the dance.

It was my reintroduction to my body, in place, that rescued me in hundreds of ways and began opening gates that continue to clatter and bang.

Through my body, running, on the move and when injured disembodied, grieving for my lost self.

Through my body, running, on the move, entering into a lost interior I mentioned in my letter to Jessica.

I hear God whispering in my ear on the run, just like dancing in the church hall. God, made flesh, whispers. 
Through flesh and trees and shops, signs, rivers, the white line, hills, love me back. I hear them whisper 'remember me, I never left'.

\section{Rosemary}

So, we are crowded, chair-to-chair, body-to-body, in a semicircle as she starts to close her presentation. There is something heavy hanging in the air; no victory dancing can happen here today. It is painfully obvious to me, and others (based on people's faces and bodies), that she has missed a big point. I glance around the room and wonder, 'Who will ask the question?' Because the question must be asked.

People look away, turn their bodies away from her ... glance at their phones. The discussion/question period proceeds, the stilted two-step of a 10-year-old's first school dance: question-response ... question-response ... question-response. I am becoming more and more disheartened. 'Why is no one asking the question?' I look at the usual instructors. And the answer is there. One of them is asleep.

So, one small voice raises her hand; she moves from being the wallflower to the dance floor and asks the question.

'I am curious why you haven't taken the racial dynamics into consideration in your intervention'.

The question hangs there like a note that has gone on for far too long.

'Well', she responds, 'I didn't think the system was ready'.

'System wasn't ready?' asks the small voice.

Long pause.... Has the orchestra gone out for a cigarette?

'I wasn't ready', she admits.

Then I pipe in. 'I am sorry we didn't support your learning so you think that you could. What do we need to do differently?'

I look over to the instructor who is asleep. He has long ago dozed and drifted off to the music of a lullaby.

But suddenly, there is more energy in the room - jitterbug energy - and the music changes.

\section{The Follow-Up}

Ken

Feeling moved by the charm, character, and vigour of these writings, I began to wonder again about how these collaborations, these shifting bodies of writing, 
existing in the play of actuality and virtuality, are activist. What is it they are doing? How are they working together? How do the multiplicities of these collaborating bodies come together in ways that other things happen, change results, and are knowable in the translucence of becoming? So since reading these clear and vibrantly active bodies of writing, when they arrived in my mailbox after the conference in May, I have found myself charged by the question: What is it that makes this body of writing, this clearly collaborative work, activist? How does it collectively perform itself? What does it do?

I have been reading about capoeira, originally a Brazilian dance form that had been adapted from a mixture of cultural differences during the early days of Portuguese colonialism, when slaves, who were taken from West Africa to Brazil, engaged in the dance both as a means of maintaining certain cultural allegiances whilst, at the same time, through the creation of new forms, attempting to resist the impositions and depredations of their incarceration and enslavement. Hence, within the musical and rhythmical elements of this emergent cultural 'in-formation' (Manning, 2007), actions such as a violent swing of the arm or a kick of the leg could be disguised as passionate dance movements, nurturing the potential of the entanglement of shared belief and possible future action. This thinking about the politics of the dance led me again to Erin Manning's work where, in the introduction to her book Politics of Touch, she says of dancing the tango:

There is no clean slate onto which politics are written and politics are made ... (p)olitics - like bodies - emerge out of frictions, accidents, disagreements, and interlockings that are both firmly institutionalised within pre-constituted space-times and that create emergent space-times. (2007, p. xvii)

It seems to me that this claim has some resonance with the movements and sensations that appeared in our workshop in May and that are further presencing in the short pieces that are offered here in this composite article. In this it feels that each piece exists within and contributes to a collaborative and collaborating 'field of play' (Richardson, 1997) in which ontological emergences dance with the show of tentative knowings that are present in each of the writings. In the movements and sensations of the dance, there are structures and forms which, in the excited energy of the 'field of play' of their presentation, give way to the processual structuring and 'in-formation' (Manning, 2010) of the flowing transmutational and always becoming immediation of the showings that are on offer here. I sense that if the opportunities to write were offered again, new bodies would appear, the writings would continue in their 
emergence, challenging the privileging of substance and the metaphysics of being that so often can be seen to accompany it. This is the inspirational, the extemporisational and the experimental activism that can be seen to emerge from collaborative writing and that can move into the processual 'methodogenesis' (Gale, 2018) of a 'creative-relational inquiry' (Wyatt, 2018) driven approach. Therefore, each piece of writing is an embodiment that, in the always emergent movements of the dance, ceases to be embodied by its improvisational challenge to the fixities of structure and form. In this respect, the bodies of writing are activist in the way that Deleuze and Guattari's (1987) 'body-without-organs' is activist: In each movement of the dance, in the processual research-creation of the collaborative touch, frisson and intra-action of the field of play, bodies are becoming. In the 'agencement' (Deleuze \& Guattari, 1987) of the constant processual writing flow, each body is potentiate; in each glancing, lingering touch of the dancing bodies, something happens. Each encounter is event/ful, each body has the capacity to affect and, within the complex intricacies of these movements, to be affected. Animate, animated, and animating bodies, 'bodieswithout-organs', are existent because they are always on the move. They are not contained, they are always more than one, and thus bodies that dance are always in-formation in collaboration, always reaching toward one another, always 'worlding' (Stewart, 2010). This is the 'politics of touch' (Manning, 2007) where the becoming of bodies in collaborative play always has the potential to create change, to resist the vapidity and control of systems of representation and interpretation and, in the multiplicity and incessance of encounter, to be enthusiastically agentic in resisting the fixity of the known and in encouraging the sensing of the not yetness of the new.

\section{Notes}

1. This reading is taken and adapted from Gale and Wyatt (2019).

2. Tearing, with the double sense of 'weeping' and 'ripping'.

3. 'Claire' is a pseudonym for a participant in this workshop who contributed to this article but has chosen not to be named as a coauthor.

\section{References}

Barad, K. (2007). Meeting the universe halfway: Quantum physics and the entanglement of matter and meaning. Durham, NC: Duke University Press.

Braidotti, R. (2013). The posthuman. Cambridge, England: Polity Press. 
Deleuze, G., \& Guattari, F. (1987). A thousand plateaus: Capitalism and schizophrenia. London, England: Athlone.

Gale, K. (2018). Madness as methodology: Bringing concepts to life in contemporary theorising and inquiry. London, England: Routledge.

Gale, K., \& Wyatt, J. (2019). Autoethnography and activism: Movement, intensity, and potential. Qualitative Inquiry, 25, 566-568. doi:10.1177/1077800418800754

Guttorm, H. E., Hilton, K. A., Jonsdottir, G. U., Löytönen, T., McKenzie, L., Gale, K., \& Wyatt, J. (2012). Encountering Deleuze: Collaborative writing and the politics of stuttering in emergent language. International Review of Qualitative Research, 5, 377-398. doi:10. 1525/irqr.2012.5.4.377

Jackson, A., \& Mazzei, L. (2012). Thinking with theory in qualitative research: Viewing data across multiple perspectives. London, England: Routledge.

Madison, D. S. (2010). Acts of activism: Human rights as radical performance. New York, NY: Cambridge University Press.

Manning, E. (2007). Politics of touch: Sense, movement, sovereignty. Minneapolis: University of Minnesota Press.

Manning, E. (2010). Always more than one: The collectivity of a life. Body and Society, 16(1), 117-127. doi:10.1177/1357034X09354128

Manning, E. (2016). The minor gesture. Durham, NC: Duke University Press.

Massumi, B. (2015). The supernormal animal. In R. Grusin (Ed.), The nonhuman turn (pp. 119). Minneapolis: University of Minnesota Press.

Richardson, L. (1997). Fields of play: Constructing an academic life. New Brunswick, NJ: Rutgers University Press.

Spinoza, B. (2002). Baruch Spinoza: The complete works (M. L. Morgan, Ed., S. Shirley, Trans.). Indianapolis, IN: Hackett.

Spry, T. (2001). Performing autoethnography: An embodied methodological praxis. Qualitative Inquiry, 7, 706-732. doi:10.1177/107780040100700605

Stewart, K. (2010). Afterword: Worlding refrains. In M. Gregg \& G. J. Seigworth (Eds.), The affect theory reader (pp. 339-354). Durham, NC: Duke University Press.

Wyatt, J. (2018). Therapy, stand-up, and the gesture of writing: Towards creative-relational inquiry. London, England: Routledge.

\section{About the Authors}

Ken Gale is a lecturer in the philosophy of education in the Faculty of Arts and Humanities at the University of Plymouth. His most recent book, Madness as Methodology: Bringing Concepts to Life in Contemporary Theorising and Inquiry, was published by Routledge in March 2018.

Jonathan Wyatt is professor of qualitative inquiry and director of the Centre for CreativeRelational Inquiry at The University of Edinburgh. His new book, Therapy, Stand-up and the Gesture of Writing: Towards Creative-Relational Inquiry, is published by Routledge.

Jessica Smartt Gullion is associate professor of sociology at Texas Woman's University. Her research interests include posthumanism and social science methodology in the ontological turn. She has published more than 30 journal articles and book chapters in venues such as 
Qualitative Inquiry, the International Review of Qualitative Research, and the Journal of Applied Social Science. Her latest books include Diffractive Ethnography and Writing Ethnography.

Ninian Hou is my English name, my Chinese name is Han-yang Hou. I am an undergraduate student at the University of Taipei, majoring in psychology and counseling. Since my professor, Min-chun Chiang, introduced autoethnography to me, I am working to combine autoethnography with counseling, using these ideas to develop a new localized counseling approach. I am also interested in hermeneutic phenomenological research methods and how collectivist culture influences gender identity.

Christopher Jeansonne is a PhD candidate in the Department of Arts Administration, Education, and Policy at The Ohio State University. His dissertation is a qualitative action research study involving the use of critical pedagogy methods in a university-level course on superheroes across media. His research interests include transnational and transmedial popular culture, media pedagogy methods and theory, and intersections between critical and creative practice.

Sheridan Linnell is associate professor of art therapy at Western Sydney University, Australia. Sheridan's work explores the place of therapy in the making of contemporary selfhood. She is interested in how arts-based and narrative approaches and feminist, poststructural, and new materialist theories contribute to inclusive accounts of the subject in more posthuman ways. Sheridan also writes poetry and engages in collaborative installation and performance art with colleagues and friends.

Melanie Reaves is an assistant professor of education at Montana State University Billings in the College of Education. She holds a Ph.D. in curriculum and instruction, literacy education with a minor in qualitative research methods. Her research focuses broadly on language/ literacy and sociocultural processes within learning and teaching. Her work is situated within qualitative and postqualitative inquiry, recently moving towards the use of arts-based methods of inquiry.

Rosemary C. Reilly, PhD, CCFE, is an associate professor in the Department of Applied Human Sciences at Concordia University in Montreal, Quebec, Canada. She is also a Member Scholar Academic of the International Institute for Qualitative Methodology. Her research areas of interest include the impact of trauma on neighborhoods and communities, collective healing strategies and systemic resilience, creativity, and qualitative and arts-based research methodologies.

Paul Rhodes is an associate professor at the Clinical Psychology Unit at The University of Sydney. In clinical terms his long-term interests have been developmental disabilities, anorexia nerves, and family therapy. In his contemporary work, however, he is exploring the decolonisation of clinical psychology, the interplay between cultural and clinical psychology, ethnographic writing, and arts-based inquiry. 